to be successful, must be based on scientific research, and the want of intimate association between the manufacturers and the workers in science. The advisory committee which has been already appointed by the Board of Trade for the consideration of many emergency questions which have arisen, should be replaced by a permanent Standing Committee of the nature of an intelligence department serving the large and growing chemical industries of the country in the same way that the Commercial Intelligence Department serves merchants and traders. It was urged that the chemists of the country generally consider it imperative on national grounds that the development of the new organisation should be pushed forward with as little delay as possible; the exparision of the chemical industries of the country requires intimate co-operation between men of science and manufacturers, and, in view of the leeway which has to be made up, a considerable increase in the number of research workers is necessary in order to hasten progress and to insure the permanent retention of new manufactures after the war. The speakers insisted upon the need for a more intelligent appreciation of the significance of original scientific work by the Government, the urgency for increased facilities of communication between manufacturers and scientific ohemical experts, and the fact that an intelligenee department of the kind contemplated would; under Government auspices, form a clearing house for all the vast variety of scientific and technological chemical material which is at our disposal; such a department would form a link between the university or college, in which the chemical technologist must be trained, and the industries which would be of immense advantage to both teacher and student. The use which might have been made of the expert knowledge of such a body during the recent preliminaries to the foundation of British Dyes, Ltd., was also indicated.

Mr. Runciman, in reply to: the deputation, pointed out that the Board of Trade fully appreciated the extent to which national progress is dependent upon the utilisation of the services of men of science, and the importance of provision for the thorough training of a very much larger number of industrial chemists than are at present available, $\mathrm{He}$ agreed with the views expressed as to the need of closer co-operation between manufacturers and scientific workers and teachers. The war had shown the weakness of our position in certain important respects, and he was in full sympathy with the general views expressed by the deputation. The actual proposals would receive careful and sympathetic consideration.

Mr. Pease informed the deputation that the particular problems to which it had directed attention had been present to. the Board of Education for some time past, and that a scheme had been approved in principle by which substantial additional assistance would be given by the Government to scientific education and industrial research. He hoped that, though the funds immediately available might not be large, they would be sufficient to enable an organisation to be brought into being at an early date which would be capable of expansion afterwards. : Mr. Pease further expressed his appreciation of the offer of assistance and advice by members of the societies represented at the deputation.

Sir William Crookes expressed the thanks of the members of the deputation for the sympathetic reception which they had met.

\section{SIR WILLIAM R. GOWERS, F.R.S.}

THE death of Sir William Gowers on May 4 , at the age of seventy, deprives English medicine of one of its most illustrious ornaments. The state of his health-which suffered an almost complete eclipse by the death of his wife two years ago-had led to his retirement from active practice, so that the news of his death cannot have been quite unexpected. Yet it will be widely regretted, and the value of his work on the scientific side of medicine will perhaps be more completely realised than if his death had been delayed for some years.

William Richard Gowers was born on March 20, r845. He was educated at Christchurch School, Oxford, and was for a time apprenticed to Dr. Simpson, a medical practitioner in Essex. He began his medical education at University College Hospital, London, and he had a brilliant career there, and at the University of London. $\mathrm{He}$ qualified M.R.C.S. 1867 , took his M.B. degree in 1869, and his M.D. in 1870, winning the Gold Medal in Medicine. He became a Fellow of the Royal College of Physicians in 1879 . He was also elected a Fellow of the Royal Society. He received the honour of knighthood in 1897 .

Gowers's great work in medicine was in systematising the important class of nervous diseases, and in bringing into relation clinical facts with pathological changes. His early works were especially remarkable in this respect, and his clinical teaching-which was peculiarly stimulating to qualified medical men and senior studentsalways had this as its keynote. He would discuss fully the symptoms of what a patient complained, the clinical signs associated with these, and finally lay down definitely and clearly the changes in the nervous system which his experience had taught him were associated with these signs and symptoms.

It is not necessary here to enumerate the various medical works which he published, or to emphasise their importance. Several of them were translated into more than one European language. His chief work was the "Manual of Disease of the Nervous System," published in two volumes, the first in 1886 and the second in I888.

Like many busy men he had, or made time for, hobbies. He was an artistic and skilful etcher, and had a great interest in, and an intimate knowledge of mosses, and also of ordinary wild flowers. $\mathrm{He}$ was also interested in archæology and architecture, and he himself investigated the remains of some of the old Suffolk churches, and described 
their character and reconstructed their history. He had early struggles and difficulties which sometimes made him seem a little austere, but as time went on his innate kindness asserted itself more and more, and his death will be deeply mourned, not only by those who benefited from his professional skill and knowledge, but by many who had experienced generous kindness at his hands.

\section{NOTES.}

AMONG the numerous portraits exhibited at the Royal Academy this year three may be specially mentioned. That of Sir Archibald Geikie, painted by Mr. R. G. Eves for presentation to the Royal Society, is a successful and welcome addition to the series of portraits of past-presidents of the society. The Hon. John Collier's portrait of Mr. C. V. Boys is not only excellent in itself, but also noteworthy for the skilful treatment of an experiment in thin films. A portrait of Dr. E. A. Wilson by Mr. H. G. Riviere, destined for Cheltenham College, is of melancholy interest as an appropriate memorial to the naturalist of the National Antarctic Expedition. A striking oil painting by Mr. John Cooke, forms a memento of a discussion on the Piltdown skull which was held in the conservator's room at the Royal College of Surgeons in June, 1913. Prof. Arthur Keith sits at a table covered with the remains of the skull, restored models, and specimens for comparison, while Prof. Elliot Smith stands behind on his right pointing to the disputed middle line of the cranium. Mr. Charles Dawson and Dr. Smith Woodward also stand behind on his left, and Sir Ray Lankester sits at the end of the table beneath them. Prof. A. S. Underwood and Mr. W. P. Pycraft are seated, one on either side of Prof. Keith, and the modeller of the restorations, Mr. F: O. Barlow, stands behind Prof. Smith. All the portraits are excellent, and the composition of the group is pleasing.

Prof. E. W. Marchant, of the University of Liverpool, has been elected chairman of the Liverpool Engineering Society for the coming year.

WE learn from the Lancet that Prof. R. Newstead, of the Liverpool School of Tropical Medicine, is in France, prosecuting entomological investigations from the point of view of military sanitation.

The Pereira medal of the Pharmaceutical Society has been awarded to Miss Dora F. White, and the silver and bronze medals of the society to Mr. A. J. Somer and Mr. R. W. Bowles respectively.

We learn from Sicience that the Draper medal was presented to Dr. Joel Stebbins, professor of astronomy at the University of Illinois, at the annual dinner of the National Acadeniv of Sciences, held on April 20.

Mr. T. R. Greenougil and his mother have given, in memory of the late Alderman T. Greenough, a complete electrical and radiagraphic installation to the Leigh Infirmary. It is in three divisions, and its value is estimated at about 5000 .

TuE Swarthmore lecture of the Society of Friends for the present year will be delivered at the Central NO. 2376 , VOL. 95]
Hall, Westminster, on Tuesday next, May 18 , at 7.30 p.m., by Prof. Silvanus P. Thompson, who will speak on "The Quest for Truth." There will be no charge made for admission.

IN Egyptian Illustration for May Mr. W. G. Kemp announces his discovery of a partially fossilised human skull and associated remains in a cavern in the limestone of the Mokattam Hills, near Cairo. The specimens, which are considered to be prehistoric, are now being studied by Dr. Ferguson at the Cairo School of Medicine.

Mr. G. MASsEe has retired from his position as head of the cryptogamic department in the herbarium at the Royal Botanic Gardens, Kew. Mr. Massee joined the Kew staff in $\mathbf{1 8 9 3}$, in succession to Dr. M. C. Cooke, and he has rendered valuable service to agriculturists and horticulturists throughout the British Empire in all questions concerning plant pathology.

We regret to learn of the death of Prof. Erich Harnack, director of the pharmacological institute of the University of Halle, and a brother of the wellknown Adolf Harnack. The deceased, a native of the Baltic provinces, was a pupil of Schmiedeberg, in conjunction with whom he prepared, from choline, so-called synthetic muscarine, at one time believed to be identical with the poison of Amanita muscaria.

We learn from the Irish Naturalist that the following naturalists in Ireland are among those who have been given commissions in the Army in connection with the present call to national service :-Prof. Gregg Wilson, professor of zoology, and Dr. A. R. Dwerryhouse, lecturer in geology, Queen's University, Belfast ; Prof. H. A. Cummins, professor of botany and agriculture, University College, Cork; Mr. C. M. Selbie, of the National Museum, Dublin; Mr. G. P. Farran and Mr. A. B. Hillas, of the Fisheries Office; Mr. H. T. Kennedy and Mr. R. L. Valentine, of the Geological Survey.

The Pioneer Mail for April 16 states that in spite of delays due to the European ivar, Sir Leonard Rogers's scheme for establishing a School of Tropical Medicine in Calcutta is progressing satisfactorily, and the time when the building will be ready for use is well in sight. The aim of the institution is to inve'stigate specially the cause of tropical diseases and render the best possible relief on practical lines with the view of finding more accurate methods of diagnosis and improved treatment. The fund for building a hospital for tropical diseases now amounts to about 14,oool. (paid up), including a recont anonymous donation of 27ool: through Dr. K. C. Buse. Plans for the hospital are nearly ready, and the building is expected to be commenced very shortly.

THE third Wilbur Wright. Memorial Lecture of the Aeronautical Society will be delivered by Prof. G. H. Bryan, on May 20, at the Royal Society of Arts, John Street, Adelphi. Gold medals of the society, awarded respectively to Prof. Bryan and to the late Mr. E. T. Busk, will be officially presented immediately before 